\section{Early adolescent childbearing in Colombia: time-trends and consequences}

\author{
Maternidad prematura adolescente en Colombia: \\ tendencias temporales y consecuencias
}

\section{Gravidez precoce na adolescência na Colômbia: tendências temporais e consequências}

Marta Cecilia Jaramillo-Mejía 1

Dov Chernichovsky 2,3

doi: 10.1590/0102-311X00020918

\begin{abstract}
Teenage childbearing has been increasing, especially among girls aged 10 to 14 years, slowing the improvements in public health and propelling social marginalization. The objective of this article is to study adolescent pregnancy in Colombia and suggest possible policy interventions. The study comprises univariate and multivariate analyses that examine trends and correlates of teenage childbirth and related infant mortality in Colombia between 2001-2011 using complete vital statistics. The study compares, by relative risk analysis as well, two groups of teenage mothers, aged 10 to 14 years and 15 to 19 years, with a reference group of mothers aged 20 to 34 years. During the study period, the average of annual birth rates increased $2.6 \%$ and $0.8 \%$ in mothers aged 10 to 14 years, and 15 to 19 years respectively, whereas it declined at an average rate of $0.2 \%$ annually for mothers aged 20 to 35 years. Simultaneously, while the overall rate declined, the infant mortality rate (IMR) of the youngest group was consistently higher during the entire period compared to the IMR of older groups. Compared with the other groups, mothers aged from 10 to 14 were more likely to be unmarried, rural, indigenous or afro-descendant, and have less access to health care. The study demonstrates that early teenage childbirth is a growing challenge at least in Colombia. These mothers are at higher risk of losing their babies while being poor and remaining poor. The study suggests the need for policy that targets appropriate education and health care to poor girls as early as age 10 and even younger.
\end{abstract}

Reproductive Behavior; Pregnancy in Adolescence; Infant Mortality; Social Determinants of Health

\section{Correspondence}

M. C. Jaramillo-Mejía

Departamento de Gestión Organizacional, Universidad Icesi. Calle 18\#122-135, Cali - Valle del Cauca 76001, Colombia. mcjara@icesi.edu.co

1 Departamento de Gestión Organizacional, Universidad Icesi, Cali, Colombia.

2 Ben-Gurion University of the Negev, Jerusalem, Israel. 3 Taub Center for Social Policy in Israel, Jerusalem, Israel. 


\section{Introduction}

Globally, teenage mothers, aged 10 and 19 years, are responsible for $11 \%$ of total births; $90-95 \%$ of these births occur in low and middle-income countries 1,2,3. Adolescent pregnancy has been increasing even in relatively traditional societies such as Colombia. The phenomenon of teenage childbearing slows the improvements in public health and propels social marginalization 4,5,6.

Adolescent pregnancies are most likely to result in abortion 7. If a teenage pregnancy is not terminated, the health of the mother and the fetus are at risk, as well as the newborn's health. This is especially true if the mother is younger than 15 and is therefore unlikely to be mature enough, physically or psychologically, to cope effectively with the challenges of pregnancy $1,2,3,7,8$. Infants of teenage mothers are at higher risk of neonatal death than infants of older mothers 2,9. Mothers in the youngest age group are at higher risk of preeclampsia, eclampsia, premature rupture of membranes, hemorrhage, and have an increased probability of delivering preterm and low birth weight infants $1,2,6,7,8,10,11$.

In addition, teenage mothers are more likely than older mothers to not have a partner to support them economically and emotionally, and most of them drop out of school early 9 . Teenage mothers are likely to come from poor households, resulting in malnutrition of the child and mother in the short term and in the perpetuation of poverty in the long term 7,12. Pregnancy in girls aged 10 and 14 years is also an issue of concern because it has been associated with sexual abuse 8,13,14,15,16.

Colombia's population of 49.4 million people (2017) is spread over an area of 1.14 million square kilometers 17. The current Colombian healthcare system was established in 1993 18. It comprises two main public health insurance regimes: the contributory regime, covering about $40 \%$ of the population in the formal economy, and the subsidized regime, covering $53 \%$ of the population in the poorer, less formal, largely rural economy. The remaining $7 \%$ of the population is nearly equally split between the uninsured and those with privileged insurance arrangements, such as teachers and the military. During the study period (2010-2011), contributory regime members were entitled to a health care package that was superior to that of subsidized regime members 19,20 . The division between the two insurance regimes has become a key socioeconomic marker in Colombia.

In 2012, the official Colombian infant mortality rate (IMR) reported by the Ministry of Health was 12.76 deaths per 1,000 live births 21 . That same year, $95 \%$ of births were reported to have been attended by physicians in hospitals with women receiving an average of more than four prenatal control visits 21,22. Still, wide regional and socioeconomic disparities affect access to care and the infant mortality persists 23 .

The aim of our study was to document the situation regarding teenage pregnancy in Colombia in order to suggest potential avenues for intervention and to improve pertinent public health and social policies. To this end, we began by establishing the trends of teenage births and infant mortality in Colombia from 2001 to 2011, and then analyzed their sociodemographic and medical correlates for 2010 and 2011. Restrepo et al. 8 suggested that the pregnancies of teenage mothers over 15 years follow patterns that are similar to those of older mothers. Consequently, we focused this study on the younger group, girls aged 10 to 14 years, while addressing mothers aged 15 to 19 years as well.

The hypotheses underlying the study were that early teenage fertility and related infant mortality are driven by marginal socioeconomic circumstances, and that infant mortality was further exacerbated by inadequate care, both during pregnancy and after delivery.

\section{Methods}

\section{Study design and setting}

The study analyzed all records of live births in Colombia from 2001 through 2011 recorded in the vital statistics registry of the National Administrative Department of Statistics (Departamento Administrativo Nacional de Estadística - DANE). Specifically, the study analyzed the entire population of 7,735,624 babies born alive (after more than 20 weeks of gestation and weighing more than 500 grams) and the 121,028 of whom eventually died during the first year of life. Data included demo- 
graphic and socioeconomic characteristics of the mothers, their access to healthcare services, and the medical treatment they and their infants received as well as statistics on the newborns including birth weight, gestation age, and Apgar score (a score below 4 in the first minute of life indicates that the baby needs medical intervention, such as resuscitation 24 .

\section{Risk groups}

The population of mothers and their newborn babies was divided into three comparative risk groups: early teenage mothers aged 10 to 14 years; adolescent mothers age 15 to 19 years 25 ; and adult mothers aged 20 to 35 years $25,26,27,28$. The latter group served as a reference to study the distinctiveness of teenage mothers. Mothers older than 35 were excluded from the analysis because this age group also carries a higher risk of infant mortality 23 .

\section{Trend analyses}

We conducted a temporal trend analysis for the period between 2001 and 2011 and cross-sectional analyses jointly for 2010 and 2011, the latest years for which data were available. Although the entire population was studied, to improve predictability, we combined these two years to overcome the small number of observations, with relatively large variations, of infant deaths during the first year of life among early teenage mothers.

The trend analyses established the average rates-of-change in birth and IMRs in the three age groups. To this end, we used the semi-logarithmic linear regression estimate of $Y_{x}=e^{\alpha+\beta x}$, where $Y_{x}$ is the observed relevant rate for the year $x=2001 \ldots 2011$, $e^{\alpha}$ is the trend line estimate of the initial point of the 2001 rate, and $\beta$ is the average rate of change over the period.

The cross-sectional analysis begins with the distribution of the demographic, socioeconomic, and medical care correlates of births, which includes the distribution of birth weights and gestation ages of live births. The distribution was complemented by odds ratio calculations of the correlates of each of the two teenage groups in comparison with the correlates of the reference group of adult mothers, with births of the three groups as the outcome. Then, the cross-sectional analysis were divided into two: an analysis of live births and an analysis of infant deaths.

\section{Analysis of live births}

Due to the unavailability of data on women who did not give birth, we could not estimate the singular association of plausible predictors on the probability of a live birth in each risk group. Consequently, we used a multinomial logistic regression model to estimate adjusted odds ratios of such predictors of a birth among teenage mothers compared with the reference category of adult mothers. These predictors include the following characteristics: indigenous or black versus other population groups, unmarried or alone versus married status, rural versus urban areas of residence, subsidized or noninsured regimes status versus (superior insurance) contributory regime, and 2011 as year of delivery versus 2010 .

\section{Analysis of infant deaths}

Because the vital statistics registry also includes data about births and deaths of infants, we used logit regression to estimate the adjusted odds ratios of plausible contributors to the probability of infant death during first year of life for each age category. These predictors are as previously described in analysis of live births as well as whether the birth was a hospital delivery or a cesarean delivery. The last two variables were not included in the analysis of live births because of poor predictive power.

It is noteworthy that the study was based on the actual populations and not on samples. That is, any reference to statistical significance should be interpreted as the predictive power of the result. 


\section{Ethics}

This paper has no ethical risk or conflict of interest. It involves no human experiments and the subjects of the study cannot be identified. It has been approved by the Ethics Committee of Icesi University.

\section{Results}

Births delivered by teenage mothers as a share of total births in Colombia rose during 2001-2011, with a larger percentage point increase among mothers aged 10 to 14 years. The average annual rate of increase in birth rate was $2.6 \%$ among early teenage mothers and $0.8 \%$ among adolescent mothers; simultaneously, the average annual birth rate among mothers aged 20 to 35 years declined by $0.2 \%$ (Figure 1). In relation to the fertility rate, these data follow a decrease in birth rates of $2.0 \%$ and $0.9 \%$, in an annual average, of mothers aged 15 to 19 years and 20 years and older, respectively, and an average annual increase of $1.4 \%$ in the birth rate of girls aged 10 to 14 years (data available from authors). Thus, the driving force behind the decrease in the share of infant mortality among mothers aged 10 to 14 years was also the increase in fertility rates in the group.

Infant deaths among teenage mothers, as a share of all infant deaths, also increased during the same period, despite overall declines in numbers. The average annual rate of decline in the IMR was 2.7\% among mothers aged 10 to 14 years, $2.1 \%$ among mothers aged 15 to 19 years, and $4.8 \%$ among mothers aged 20 years or older (Figure 2). Despite sharp annual variations in the IMR among mothers aged 10 to 14 years, the rate was consistently higher than the IMR of the other age groups. After 2009, the IMR among mothers aged 15 to 19 surpassed that of mothers aged 20 to 35 years.

Demographic, socioeconomic, and medical correlates as well as birth outcomes of early teenage pregnancy in Colombia are robust. Teenage mothers are distinct with regard to each correlate as measured by the odds ratios, relative to the reference group of mothers aged 20 to 35 years (Table 1). The odds of an early teenage mother being indigenous or black are 1.5-2.0 times higher than that of the other age groups. The odds of teenage mothers in general and early teenage mothers in particular being unmarried, having the lower quality health insurance package or no insurance at all, and living in rural areas are several times higher than those of the reference age group.

\section{Figure 1}

Birth rates (per 1,000 live births) by mother's age group. Colombia, 2010-2011.

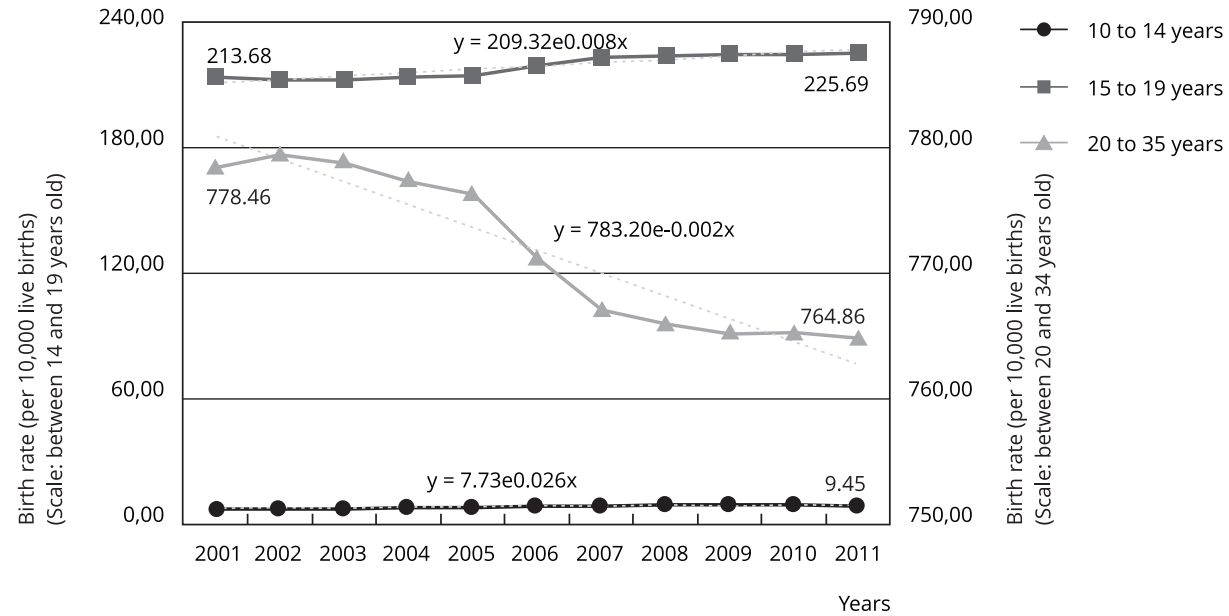




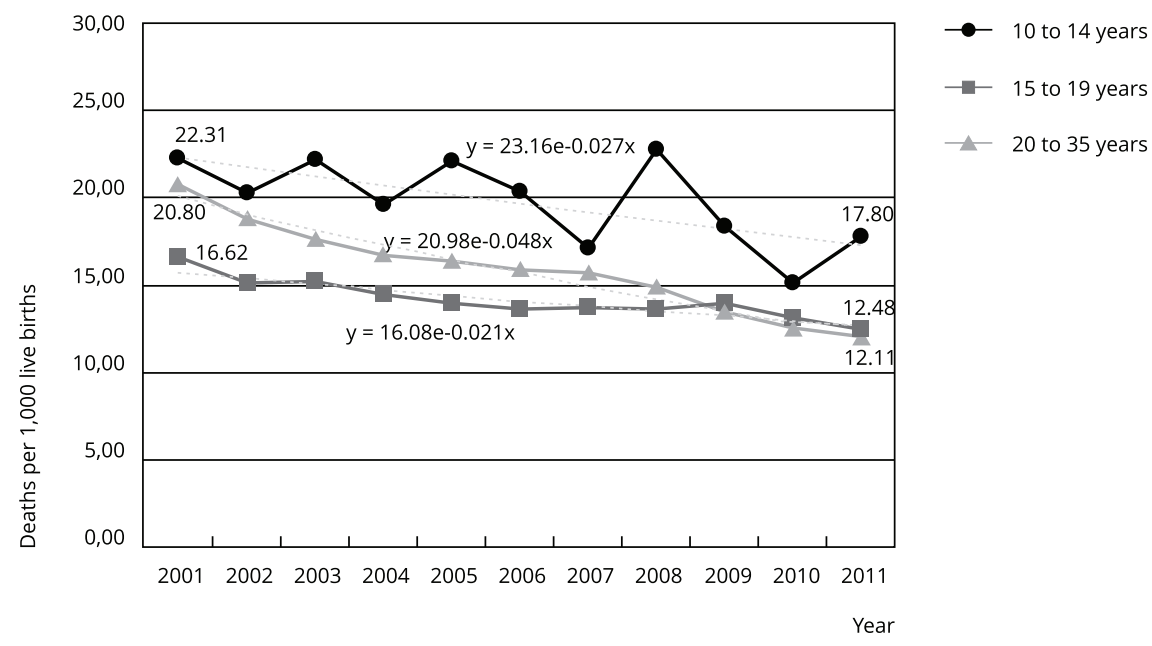

As for medical care, teenage mothers had fewer prenatal visits than mothers aged 20 to 35 years. On average, early teenage mothers had 1.27 fewer visits per pregnancy than mothers in the reference group, and adolescent teenagers had 0.66 fewer visits than the reference group. The odds ratios suggest that the likelihood of early teenage mothers giving birth close to home, in the municipality of residence, is similar to that of mothers aged 20 to 35 years, with adolescent teenagers being more likely to give birth close to home than the other two groups. The percentage of women delivering in a hospital and with a doctor in attendance was similar across all three age groups. However, despite the similar percentages, teenage mothers - the younger ones in particular - received inferior attention as indicated by the odds ratios. Simultaneously, the early teenage mothers were more likely than mothers in the reference group to have a cesarean delivery whereas the older group of teenage mothers was less likely.

The relatively adverse socioeconomic and demographic circumstances of teenage mothers translated into comparatively inferior birth outcomes: teenage mothers were more likely to give birth prematurely and to give birth to low weight babies. Babies born to teenagers aged 10 to 14 years were 1.5 times more likely, and babies born to teenagers aged 15 to 19 years were 1.3 times more likely, than babies born to adult mothers to have critically low 1-minute Apgar scores $(<4)$ and to need medical intervention.

Since the demographic and socioeconomic characteristics are correlated (at levels of up to about 0.25 ), the adjusted odds ratio provide a closer look at the relatively significant predictors for teenage childbirth (Table 2). While controlling for other variables in each instance, in comparison with adult mothers aged 20 to 35 years, early teenage mothers aged 10 to 14 years were 1.23 times more likely to be afro-descendants (a black minority) and adolescent mothers aged 15 to 19 years were less likely to be "others" (with an adjusted odds ratio of 0.96 ). Early teenage mothers were 5.58 times more likely, and adolescent mothers were 2.61 times more likely, to be single; early teenage mothers were 3.30 times more likely and adolescent mothers were 2.33 times more likely to have inferior health insurance; and early teenage mothers were 1.60 times more likely and adolescent mothers were 1.14 times more likely to live in a rural area.

Adjusted odds of infant mortality indicate that certain demographic and socioeconomic correlates are predictors of early infant death across all age groups studied. These predictors include belonging to a black or indigenous minority population, being single, living in a rural area, and having an 


\section{Table 1}

Mean live births and infant mortality rates (IMR) and distributions of mother and child characteristics and unadjusted odds ratios by mother's age group. Colombia, 2010-2011.

\begin{tabular}{|c|c|c|c|c|c|}
\hline \multirow[t]{2}{*}{ Variables } & \multicolumn{3}{|c|}{ Mothers } & \multicolumn{2}{|c|}{ Unadjusted odds ratio } \\
\hline & 10 to 14 years & 15 to 19 years & 20 to 35 years & 10 to 14 years & 15 to 19 years \\
\hline \multicolumn{6}{|l|}{ Basic details } \\
\hline Number of births (\%) * & $12,606(1.16)$ & $297,502(27.45)$ & $773,521(71.38)$ & & \\
\hline IMR (infant deaths per 1,000 live births) & 15.20 & 13.16 & 12.62 & & \\
\hline \multicolumn{6}{|l|}{ Demographic ** } \\
\hline Indigenous & 3.55 & 2.15 & 1.83 & $1.98 * \star *$ & $1.18 * \star \star$ \\
\hline Black (afro-descendant) & 8.46 & 6.54 & 5.76 & $1.52 * \star \star$ & $1.15 * \star \star$ \\
\hline Others & 85.78 & 89.24 & 90.47 & $0.60 * \star *$ & $0.86 * \star \star$ \\
\hline Unmarried or alone & 44.46 & 27.91 & 12.85 & $5.56 * \star \star$ & $2.64 * \star \star$ \\
\hline \multicolumn{6}{|l|}{ Socioeconomic } \\
\hline Subsidized or non-insured regimes & 82.52 & 74.91 & 55.40 & $3.89 * * \star$ & $2.43 * \star \star$ \\
\hline Rural residence & 33.13 & 25.41 & 19.51 & $2.07 * \star \star$ & 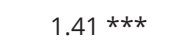 \\
\hline \multicolumn{6}{|l|}{ Medical care } \\
\hline Number of prenatal visits by mother & 4.89 & 5.50 & 6.16 & & \\
\hline Delivery in municipality of residence & 19.27 & 22.38 & 19.25 & 1.00 & $1.21 * \star \star$ \\
\hline Cesarean delivery & 43.66 & 34.64 & 41.23 & $1.11 * \star *$ & $0.76 * \star \star$ \\
\hline Hospital delivery & 98.47 & 98.74 & 98.79 & $0.79 * \star \star$ & $0.96 \#$ \\
\hline Delivery attended by doctor & 98.52 & 98.63 & 98.73 & $0.86 \#$ & $0.93 * \star *$ \\
\hline \multicolumn{6}{|l|}{ Live births outcomes } \\
\hline Multiple pregnancy & 1.08 & 1.14 & 1.74 & $0.61 * \star *$ & $0.65 * \star \star *$ \\
\hline $\begin{array}{l}\text { Very premature delivery (gestational age: } 31 \\
\text { weeks or bellow) }\end{array}$ & 2.08 & 1.35 & 1.22 & $1.73 * \star \star$ & $1.11 * \star \star *$ \\
\hline Premature delivery (gestational age: $32-36$ weeks) & 13.00 & 9.20 & 8.28 & $1.66 * \star \star$ & $1.12 * \star \star$ \\
\hline $\begin{array}{l}\text { Normal gestational age (gestational age: } \\
>36 \text { weeks) }\end{array}$ & 97.31 & 90.01 & 91.05 & $0.60 * \star \star$ & $0.89 \#$ \\
\hline Very low birth weight $(<1,500 \mathrm{~g})$ & 1.53 & 1.05 & 1.04 & $1.47 \#$ & 1.01 \\
\hline Low birth weight $(1,500-2,499 g)$ & 12.22 & 9.71 & 8.37 & $1.53 * \star \star$ & $1.18 * \star \star$ \\
\hline Normal birth weight (> 2,499g) & 87.31 & 89.88 & 91.26 & $0.66 * \star *$ & $0.85 * \star \star$ \\
\hline Apgar score $<4$ & 0.71 & 0.61 & 0.47 & $1.52 * * *$ & $1.30 * \star *$ \\
\hline
\end{tabular}

* Total represents the sum of the three age groups, without the information on mothers above 35 years $(232,174)$ and missing values $(4,323)$;

** Sum of the percentages below does not correspond to the total due to missing values;

*** Significant at $1 \%$;

\# Significant at $5 \%$. 


\section{Table 2}

Adjusted odds ratio for live births among teenage mothers compared to mothers aged 20 to 35 years. Colombia, 2010-2011.

\begin{tabular}{|c|c|c|c|c|}
\hline \multirow[t]{3}{*}{ Variables } & \multicolumn{4}{|c|}{ Age of the mother (live births) } \\
\hline & \multicolumn{2}{|c|}{10 to 14 years } & \multicolumn{2}{|c|}{15 to 19 years } \\
\hline & Adjusted odds ratio & $95 \% \mathrm{Cl}$ & Adjusted odds ratio & $95 \% \mathrm{Cl}$ \\
\hline \multicolumn{5}{|l|}{ Demographic } \\
\hline Indigenous & 1.23 * & $1.11-1.37$ & 0.89 * & $0.86-0.92$ \\
\hline Black (afro-descendant) & 1.23 * & $1.15-1.31$ & 0.96 * & $0.95-0.98$ \\
\hline Unmarried or alone & 5.58 * & $5.38-5.80$ & $2.61 *$ & $2.58-2.64$ \\
\hline \multicolumn{5}{|l|}{ Socioeconomic } \\
\hline Subsidized or non-insured regimes & 3.30 * & $3.14-3.46$ & 2.33 * & $2.31-2.36$ \\
\hline Rural residence & 1.60 * & $1.53-1.66$ & 1.14 * & $1.13-1.15$ \\
\hline \multicolumn{5}{|l|}{ Time } \\
\hline Year: 2010 & 0.99 & $0.97-1.02$ & 0.98 * & $0.97-0.99$ \\
\hline
\end{tabular}

95\%Cl: 95\% confidence interval.

* Significant at $1 \%$.

\section{Table 3}

Adjusted odds ratio of infant death (live birth as baseline), by mother's age group. Colombia, 2010-2011.

\begin{tabular}{|c|c|c|c|}
\hline \multirow[t]{3}{*}{ Variables } & \multirow{2}{*}{\multicolumn{3}{|c|}{$\begin{array}{l}\text { Adjusted odds ratio (SD) } \\
\text { Dependent variable: infant deaths }\end{array}$}} \\
\hline & & & \\
\hline & 10 to 14 years & 15 to 19 years & 20 to 35 years \\
\hline \multicolumn{4}{|l|}{ Demographic } \\
\hline Indigenous & $1.95 *(0.68)$ & $1.30 * *(0.15)$ & $1.26 * * *(0.11)$ \\
\hline Black (afro-descendant) & $1.18(0.36)$ & $1.16 * *(0.09)$ & $1.23 * * *(0.07)$ \\
\hline Unmarried or alone & $1.66 * * *(0.31)$ & $1.25 * * *(0.05)$ & $1.34 * * *(0.06)$ \\
\hline \multicolumn{4}{|l|}{ Socioeconomic } \\
\hline Subsidized and non-insured regimes & $1.45(0.41)$ & $1.24 * * *(0.06)$ & $1.32 * * *(0.04)$ \\
\hline Rural area & $1.38 *(0.27)$ & $0.93(0.05)$ & $0.98(0.04)$ \\
\hline \multicolumn{4}{|l|}{ Prenatal care and delivery } \\
\hline Cesarean delivery & $0.93(0.18)$ & $1.23 * * *(0.05)$ & $1.32 * * *(0.04)$ \\
\hline Hospital delivery & $0.35 * *(0.16)$ & $0.09 * * *(0.01)$ & $0.13 * * *(0.01)$ \\
\hline Premature delivery (gestationa age: $32-36$ weeks) & $15.62 * * *(3.09)$ & $12.62 * * *(0.52)$ & $14.07 * * *(0.39)$ \\
\hline \multicolumn{4}{|l|}{ Time } \\
\hline Year: 2010 & $0.83(0.15)$ & $0.99(0.04)$ & $0.93 * *(0.03)$ \\
\hline
\end{tabular}

SD: standard deviation.

Note: unless specified otherwise, variables assume value 1 if true, 0 if fake.

* Significant at 10\%;

** Significant at 5\%;

*** Significant at $1 \%$. 


\section{Discussion}

Our analysis of the Colombian vital statistics records shows that births delivered by teenage mothers as a share of total births increased in Colombia during the study period 2001-2011. We also found that the IMR increased among teenage mothers during the same period. This situation has also been documented in the Encuesta Nacional de Demografia y Salud (ENDS) 201022 and in recent publications on the management of pregnancy in early adolescence in Colombia, which report that in 2013 the birth rate for girls aged 10 to 14 years was estimated at 10.1 per 1,000 live births, similar to our findings $6,8,29$.

The proportion of births in Colombia by women under 15 years of age were higher than the proportion in Ecuador reported by Ganchimeg et al. 1 and even higher than the average rate in Latin America and the Caribbean, which is considered the highest rate of teenage pregnancy in the world 30 .

As we demonstrated in this study, babies born to early teenage mothers were at high risk for premature delivery and low birth weight 2 . Our calculations show odds ratios for these risks that are higher than those reported by Conde-Aguado et al. 28 and lower than those reported by Cortés Castell et al. 31. Although several studies have shown that access to prenatal care reduces the risk of complications 22 , our study shows that having an average of four prenatal visits during pregnancy was not enough to reduce complications prior to and during delivery. The infrequent use of prenatal care appointments in combination with the increased likelihood of low birth weight newborns can help explain the relative lack of improvement in IMR among babies born to teenage mothers, especially in mothers with 14 years of age or younger 6 . These conditions, in addition to inferior socioeconomic and medical circumstances, contribute to high infant mortality in this age group; many of these babies do not survive their first year due to low birth weight and prematurity 10,26.

The high teenage pregnancy rate and IMR slows socioeconomic improvement, negatively affects individual well-being, burdens public health resources, and perpetuates poverty and socioeconomic marginalization, as shown by the World Bank 30 . Teenage parents do not reach levels of education and income that allow them to improve their lives, and their children share a similar fate 28. Many authors have reported that such parents often become "absent couples", unable to fulfill their responsibilities to the children they have procreated 6,7,10.

The gross fertility rates for girls aged 14 and younger are high in Colombia, considering the age at which girls begin their sexual development and become sexually active 8,21 . Biological and environmental factors have played a part: the onset of menarche has fallen by 2-3 months per decade since the 19th century, leading to sexual maturity at earlier ages today than in the past 27 . In addition, social, economic, and health services developments have contributed to improvements in nutrition and health care $7,8,12,20,27,32$.

Taking all the data and research into consideration, however, we conclude that early teenage pregnancy and related infant mortality in Colombia are socioeconomic phenomena. The high incidence of teenage births in Colombia is most typical of black mothers who live in rural areas under poor economic circumstances and with inferior access to care ${ }^{3}$. Teenage mothers, especially early teenage mothers, are more likely than mothers aged 20 to 35 years to be members of the relatively inferior subsidized medical insurance regime. This means that teenage mothers use fewer services because of a combination of low supply and low demand. This is shown by the lower rate of prenatal care appointments made by teenage mothers.

We also note that at young ages, the sexual activity is not always voluntary; there is a high probability that girls aged 14 or younger have experienced sexual violence $13,14,33$. Rape can be a reason for abortion, which was legalized in 2006 for girls aged 14 and under. However, we observe that the number of pregnancies continued to increase even after 2006, possibly because some pregnant women learn of their pregnancy too late in its development or fear pursuing an abortion because of threats from their rapist or their families, or because of social or religious stigma 34 .

The phenomena documented here, and supported by others, persist despite efforts in Colombia to increase access to birth control, which have led to a considerable decline in fertility resulting in reducing the birthrate to close to 2.1 children per woman of childbearing age. However, while the overall fertility rate has been gradually declining, the birthrate in the teenage population does not show the same rate of decline. 
More measures - in addition to the availability of birth control - must be applied to combat early teenage childbirth in Colombia and other low- and middle-income countries that are together responsible for more than $90 \%$ of births among mothers under 20 years of age 1,2 . Reproduction and sexual health programs should involve parents so that they can raise the confidence of their children and help adolescents to make voluntary decisions and avoid succumbing to the pressures of a partner. Furthermore, these programs should consider different strategies for raising awareness about and encouraging the use of contraception and should aim to reduce violent crimes and to create conditions to avoid them 13 .

Policies should involve educators, parents, and adolescents in the promotion of adolescent sexual and reproductive rights, sexual abuse prevention and early access to voluntary termination when pregnancy occurs.

In conclusion, the results lead us to call on policymakers to review existing policies and to formulate new strategies to reduce the number of pregnancies in preteen and early teenage girls and to improve their access to better health services and public education starting with girls entering high school.

\section{Contributors}

M. C. Jaramillo-Mejía was responsible for writing the article and the management of the Colombian data and their interpretation in the context of this country. D. Chernichovsky supervised the statistical methodology and the international context of the analysis and revised the article.

\section{Additional informations}

ORCID: Marta Cecilia Jaramillo-Mejía (00000003-4055-6006); Dov Chernichovsky (00000003-3840-701X)

\section{Acknowledgments}

Data was provided by the National Administrative Department of Statistics (Departamento Administrativo Nacional de Estadística - DANE). Icesi University, Colombia, provided the research infrastructure and editing. Steven Ruiz assisted with the research for the study. The paper was edited by Gwen Diamond.

\section{References}

1. Ganchimeg T, Ota E, Morisaki N, Laopaiboon M, Lumbiganon P, Zhang J, et al. Pregnancy and childbirth outcomes among adolescent mothers: a World Health Organization multicountry study. BJOG 2014; 121 Suppl 1:40-8.

2. Althabe F, Moore JL, Gibbons L, Berrueta M, Goudar SS, Combah E, et al. Adverse maternal and perinatal outcomes in adolescent pregnancies: The Global Network's Maternal Newborn Health Registry study. Reprod Health 2015; 12 Suppl 2:S8.

3. Islam MM, Islam MK, Hasan MS, Hossain MB. Adolescent motherhood in Bangladesh: trends and determinants. PLoS One 2017; 12:e0188294.

4. Lang K, Weinstein R. The consequences of teenage childbearing before Roe $\mathrm{v}$ Wade. Cambridge: National Bureau of Economic Research; 2013. (Working Paper, 19627).

5. Azevedo JP, Favara M, Haddock SE, LopezCalva LF, Müller M, Perova E. Embarazo adolescente y oportunidades en América Latina y el Caribe: sobre maternidad temprana, pobreza y logros económicos. Washington DC: World Bank Publications; 2012.

6. Flórez CE, Núñez J. Teenage childbearing in Latin American countries. In: Duryea S, Ureta M, Cox EA, editors. Critical decisions at a critical age adolescents and young adults in Latin America. Washington DC: Interamerican Development Bank; 2003. p. 23-90.

7. Maternidad adolescente en América Latina y el Caribe: tendencias, problemas y desafíos. Desafíos. Boletín de la Infancia y Adolescencia sobre el Avance de los Objetivos de Desarrollo del Milenio 2007; (4). https://www.unicef.org/ costarica/docs/cr_pub_Desafios_maternidad_ adolescente_LAC.pdf. 
8. Restrepo OL, Diaz I, Farias N, Balcázar N, Quintero CA, Romero E, et al. Protocolo de atención a la embarazada menor de 15 años. Bogotá: Ministerio de Salud y Protección Social/Fondo de Población de las Naciones Unidas; 2014.

9. Karra M, Lee M. Human capital consequences of teenage childbearing in South Africa. https://assets.prb.org/pdf12/poppov-teenchildbearing-southafrica.pdf (accessed on 04/ Nov/2014).

10. Ramaiya A, Kiss L, Baraitser P, Mbaruku G, Hildon Z. A systematic review of risk factors for neonatal mortality in adolescent mother's in Sub Saharan Africa. BMC Res Notes 2014; 7:750.

11. Hoffman SD. By the numbers: the public costs of teen childbearing. https://www.cdc.gov/ nchs/ppt/nchs2010/29_suellentrop.pdf (accessed on 04/Nov/2014).

12. Fall CHD, Sachdev HS, Osmond C, RestrepoMendez MC, Victora C, Martorell R, et al. Association between maternal age at childbirth and child and adult outcomes in the offspring: a prospective study in five low-income and middle-income countries (COHORTS collaboration). Lancet Glob Health 2015; 3:e366-77.

13. Finer LB, Philbin JM. Sexual initiation, contraceptive use, and pregnancy among young adolescents. Pediatrics 2013; 131:886-91.

14. Hendrick CE, Cance JD, Maslowsky J. Peer and individual risk factors in adolescence explaining the relationship between girls' pubertal timing and teenage childbearing. J Youth Adolesc 2016; 45:916-27.

15. Cueto S, Leon J. Early sexual initiation among adolescents: a longitudinal analysis for 15-year-olds in Peru. Interam J Psychol 2016; 50:186-203.

16. Dávila-Ramírez F, Fajardo-Granados D, Jiménez-Cruz C, Florido Pérez C, Vergara-Castellón K. Factores de riesgo psicosocial para embarazo temprano y deserción escolar en mujeres adolescentes. Rev Cienc Salud (Bogotá) 2016; 14:93-101.

17. Universidad del Rosario. CMUDE Colombia 2015. Campeonato Mundial Universitario Debate en Español. http://www.urosario.edu.co/ CMUDE2015/Sedes/faqs/ (accessed on 24/ Mar/2017).

18. Congreso de la República de Colombia. Ley 100 de 1993. Por medio de la cual se crea el Sistema General de Seguridad Social Integral. Diario Oficial 1993; 23 dic.

19. Chernichovsky D, Guerrero R, Martínez G. La sinfonía inconclusa: la reforma del Sistema de Salud de Colombia. (Working Paper, 2012). https://www.icesi.edu.co/proesa/ima ges/docs/The\%20Incomplete\%20Symphony_ EN.pdf (accessed on 04/Nov/2014).

20. Montenegro F, Bernal O. Colombia case study: the subsidized regime of Colombia's National Health Insurance System. Washington DC: World Bank; 2013. (UNICO Studies Series, $15)$.
21. Ministerio de Salud y Protección Social. Indicadores básicos 2012: situación de salud de Colombia. Bogotá: Ministerio de Salud y Protección Social; 2013.

22. Profamilia. Encuesta Nacional de Demografía y Salud: ENDS 2010. http://profamilia.org.co/ wp-content/uploads/2015/05/ends-2010.pdf (accessed on 04/Feb/2013).

23. Jaramillo-Mejía M, Chernichovsky D, Jiménez-Moleón JJ. Brechas regionales de la mortalidad infantil en Colombia. Rev Peru Med Exp Salud Pública 2013; 30:551-9.

24. Chong D, Karlberg J. Refining the Apgar score cut-off point for newborns at risk. Acta Pædiatr 2004; 93:53-9.

25. Okumura JA, Maticorena DA, Tejeda JE, Mayta-Tristán P. Embarazo adolescente como factor de riesgo para complicaciones obstétricas y perinatales en un hospital de Lima, Perú. Rev Bras Saúde Matern Infant 2014; 14: 383-92.

26. Gibbs CM, Wendt A, Peters S, Hogue CJ. The impact of early age at first childbirth on maternal and infant health. Paediatr Perinat Epidemiol 2012; 26:259-84.

27. Chen X-K, Wen SW, Fleming N, Demissie K, Rhoads GG, Walker M. Teenage pregnancy and adverse birth outcomes: a large population based retrospective cohort study. Int J Epidemiol 2007; 36:368-73.

28. Conde-Agudelo A, Belizán JM, Lammers C. Maternal-perinatal morbidity and mortality associated with adolescent pregnancy in Latin America: cross-sectional study. Am J Obstet Gynecol 2005; 192:342-9.

29. Urdinola BP. Determinantes socioeconómicos de la mortalidad infantil en Colombia, 1993. Revista Colombiana de Estadística 2011; 34:39-72.

30. World Bank. The WDR 2012: gender equality and development. Washington DC: World Bank Publications; 2011.

31. Cortés Castell E, Rizo-Baeza MM, Aguilar Cordero MJ, Rizo-Baeza J, Gil Guillén V. Edad materna como factor de riesgo de prematuridad en España: área mediterránea. Nutr Hosp 2013; 28:1536-40.

32. Islam A, Islam N, Bharati P, Aik S, Hossain G. Socio-economic and demographic factors influencing nutritional status among early childbearing young mothers in Bangladesh. BMC Womens Health 2016; 16:58.

33. Mmari K, Sabherwal S. A review of risk and protective factors for adolescent sexual and reproductive health in developing countries: an update. J Adolesc Health 2013; 53:562-72.

34. Secretaría Jurídica Distrital de la Alcaldía Mayor de Bogotá D.C. Sentencia C-355/06 Corte Constitucional. Referencia: expedientes D6122, 6123 y 6124 Demandas de inconstitucionalidad contra los Arts. 122, 123 (parcial), 124, modificados por el Art. 14 de la Ley 890 de 2004, y 32, numeral 7, de la ley 599 de 2000 Código Penal. http://www.alcaldiabogota.gov. co/sisjur/normas/Norma1.jsp?i=21540 (accessed on $04 / \mathrm{Nov} / 2014$ ). 


\section{Resumen}

La maternidad prematura se ha visto incrementa$d a$, especialmente entre niñas con edades comprendidas entre los 10 a 14 años, aminorando mejoras en la salud pública y propagando la marginalización social. El objetivo de este artículo es estudiar los embarazos adolescentes en Colombia y sugerir posibles politicas de intervención. El estudio abarca análisis univariados y multivariados que examinan tendencias y correlacionan el parto en la adolescencia y la mortalidad infantil relacionada, en Colombia, durante el periodo de 2001 a 2011, usando estadísticas vitales completas. El estudio compara, también, mediante un análisis de riesgos relativos, a dos grupos de madres adolescentes, con edades de 10 a 14 y edades de 15 a 19 años, con un grupo de referencia, madres con edades de 20 a 34. Durante el período de estudio, la media anual de la tasa de natalidad se incrementó un 2,6\% y un $0,8 \%$ en madres con edades de 10 a 14 años, $y$ edades de 15 a 19 años, respectivamente, mientras que decreció a una tasa media de 0,2\% anualmente en madres con 20-35 años de edad. Simultáneamente, mientras disminuía en general, la tasa de mortalidad infantil (TMI) del grupo más joven fue consistentemente más alta durante todo el período que la TMI de los grupos con mayor edad. Comparadas con otros grupos, las madres con edades entre 10 a 14 años eran más propensas a no estar casadas, ser procedentes del ámbito rural, indígenas o afro-mulatas, $y$ contar con menor acceso a servicios de salud. El estudio demuestra que la maternidad prematura en adolescentes es un desafío creciente, al menos en Colombia. Estas madres tienen un riesgo más alto de perder a sus bebés mientras están en situación de pobreza. El estudio indica la necesidad de politicas que tengan como objetivo una educación apropiada y cuidados de salud, dirigidos a niñas pobres, desde una edad tan temprana como los 10 años o incluso más jóvenes.

Conducta Reproductiva; Embarazo en la Adolescencia; Mortalidad Infantil;

Determinantes Sociales de la Salud

\section{Resumo}

A gravidez na adolescência tem crescido, especialmente na faixa etária de 10 a 14 anos, freando avanços na saúde pública e impulsionando a marginalização social. O objetivo deste artigo é estudar a gravidez na adolescência na Colômbia e sugerir possíveis intervenções de políticas públicas. O estudo consiste em análises univariadas e multivariadas que examinam tendências e correlativos da gravidez na adolescência e da mortalidade infantil associada na Colômbia no período de 2001 a 2011 usando estatísticas vitais completas. O estudo compara, também por meio de análise de risco relativo, dois grupos de mães adolescentes, com idade entre 10 e 14 anos e entre 15 e 19 anos, com um grupo de referência, mães com idade entre 20 e 34 anos. Durante o período do estudo, as taxas médias anuais de natalidade aumentaram em 2,6\% e 0,8\% entre as mães com idade entre 10 e 14 e entre 15 e 19 anos, respectivamente, ao mesmo tempo em que sofreram uma redução, a uma taxa média anual de 0,2\%, entre as mães com idade entre 20 e 35 anos. Ao mesmo tempo, a taxa de mortalidade infantil (TMI) do grupo mais jovem foi consistentemente mais alta do que a dos grupos mais velhos, ainda que tenha sofrido uma redução. Quando comparadas aos outros grupos, mães com idade entre 10 e 14 anos tinham maior probabilidade de serem solteiras, indígenas ou Afro -mulatas, viverem em áreas rurais e terem menos acesso a serviços de saúde. Este estudo demonstra que a gravidez precoce na adolescência é um desafio crescente, pelo menos na Colômbia. Essas mães têm risco maior de perderem seus bebês e, simultaneamente, de serem e permanecerem pobres. $O$ estudo sugere a necessidade de politicas dirigidas à educação e serviços de saúde apropriados para meninas pobres a partir dos 10 anos e até mais jovens.

Comportamento Reprodutivo; Gravidez na Adolescência; Mortalidade Infantil; Determinantes Sociais de Saúde
Submitted on $05 / \mathrm{Feb} / 2018$

Final version resubmitted on 27/Aug/2018

Approved on 31/Aug/2018 